\title{
Perbandingan Arus Puncak Ekspirasi Perokok Elektronik dan Perokok Konvensional pada Mahasiswa Kedokteran Universitas Malahayati Tahun 2019
}

\section{Comparison of Expired Top Currents of Electronic Smoking and Conventional Smokers in Medical Students Malahayati University in 2019}

\author{
Hetti Rusmini ${ }^{1}$, Rakhmi Rafie ${ }^{2}$, Fransisca Sinaga ${ }^{3}$, Salman Alfarisi Komar ${ }^{4}$ \\ ${ }^{1}$ Departemen Farmakologi Fakultas Kedokteran Universitas Malahayati, \\ Lampung, Indonesia \\ ${ }^{2}$ Departemen Anatomi Fakultas Kedokteran Universitas Malahayati, Lampung, \\ Indonesia \\ ${ }^{3}$ Departemen Pulmonologi Rumah Sakit Bintang Amin Husada, Lampung, \\ Indonesia \\ ${ }^{4}$ Program Studi Kedokteran Fakultas Kedokteran Universitas Malahayati, \\ Lampung, Indonesi \\ *Korespondensi penulis: hetti@malahayati.ac.id
}

Penyerahan: 17-06-2020, Perbaikan: 24-07-2020, Diterima: 23-09-2020

\begin{abstract}
Electronic cigarettes are becoming popular among individuals addicted to conventional cigarettes, who are beginning to understand that using e-cigarettes (vaping) is safer than conventional smoking. Cigarettes can disrupt pulmonary physiology. One way to find out the function of pulmonary physiology is to examine peak expiratory flow (APE). The purpose of this study was to determine the comparison of peak expiration of electronic smokers and conventional smokers in medical students at Malahayati University in Bandar Lampung City in 2019. This research was in the form of a quantitative analytic with a cross-sectional data collection approach. The sample of this study was 66 students with the purposive sampling method. Data analysis using Mann Whitney Test. Comparison of peak expiratory current values in electronic smokers and conventional smokers seen from the average APE results of $88.39 \%$ and $77.36 \%$. Bivariate test results with the Mann-Withney Test showed a $p$-value $<0,001$. It meant a meaningful comparison of the peak current expiration of electronic smokers and conventional smokers in the Medical Students of Malahayati University in 2019.
\end{abstract}

Keywords: Cigarette, electronic cigarette, the peak flow of expiration.

\section{ABSTRAK}

Rokok elektronik menjadi populer di kalangan individu yang kecanduan rokok konvensional, yang mulai mengerti bahwa menggunakan e-cigarette (vaping) lebih aman dibandingkan dengan merokok konvensional. Rokok dapat menyebabkan terganggunya faal paru. Salah satu cara untuk mengetahui fungsi faal paru adalah melalui pemeriksaan arus puncak ekspirasi (APE).Tujuan penelitian ini adalah untuk mengetahui perbandingan arus puncak ekspirasi perokok elektronik dan perokok konvensional pada mahasiswa kedokteran Universitas Malahayati di Kota Bandar Lampung tahun 2019. Penelitian ini berbentuk analitik kuantitatif dengan pendekatan pengambilan data cross sectional. Sampel penelitian ini adalah 66 mahasiswa dengan metode pengambilan metode 
Purposive Sampling. Analisis data menggunakan Uji Mann-Whitney Test. Perbandingan nilai arus puncak ekspirasi pada perokok elektronik dan perokok konvensional dilihat dari hasil rata-rata APE yaitu $88.39 \%$ dan $77.36 \%$. Hasil uji bivariat dengan Uji MannWithney menunjukan $\mathrm{p}$-value $<0.001$ yang artinya menyatakan bahwa terdapat perbandingan yang bermakna arus puncak ekspirasi perokok elektronik dan perokok konvensional pada Mahasiswa Kedokteran Universitas Malahayati tahun 2019.

Kata kunci: Arus Puncak Ekspirasi, Rokok, Rokok Elektronik.

\section{PENDAHULUAN}

Merokok merupakan salah satu kekhawatiran terbesar yang dihadapi dunia kesehatan karena menyebabkan hampir 6 juta orang meninggal dalam setahun. Lebih dari 5 juta orang meninggal karena menghisap langsung rokok, sedangkan 600 ribu orang lebih meninggal karena terpapar asap rokok (WHO, 2013). Indonesia merupakan salah satu negara dengan prevalensi perokok yang terbesar di dunia. Menurut data World Health Organization (WHO), pada tahun 2012 persentase prevalensi perokok pria yaitu $67 \%$ jauh lebih besar daripada perokok wanita yaitu 2,7\%. Diantara para perokok tersebut terdapat 56,7\% pria dan $1,8 \%$ wanita merokok setiap hari. Terdapat jarak yang besar antara jumlah perokok dewasa pria dan perokok wanita yang merokok setiap hari (OECD, 2013). Diperkirakan sebanyak seperempat perokok aktif akan meninggal pada usia 15-39 tahun dan mereka kehilangan angka harapan hidup sekitar 20 tahun (Gajalakshmi dkk., 2003). Oleh karena itu, maka WHO mendirikan WHO Framework Convention on Tobacco Control (WHO-FCTC) untuk memberikan solusi terhadap persoalan tembakau yang sudah mendunia. Banyak metode yang dicanangkan WHO untuk mendukung masyarakat agar berhenti merokok, salah satunya adalah dengan menggunakan NRT atau Nicotine Replacement Therapy (terapi pengganti nikotin) (WHO, 2009).

Menurut Moore tahun 2009, Nicotine replacement therapy (NRT) adalah metode yang menggunakan suatu media untuk memberikan nikotin yang diperlukan oleh perokok tanpa pembakaran tembakau yang merugikan. Alat-alat yang sudah dikenal dan beredar secara komersil adalah gum (permen karet), inhaler, lozenges (tablet hisap), nasal spray (semprot hidung) dan skin patch. Metode NRT lain diperkenalkan tahun 2004 dan berkembang dengan cepat di seluruh dunia adalah electronic cigarette (rokok elektronik) atau ecigarette yang berbentuk mirip seperti rokok. Rokok elektronik menjadi populer di kalangan individu yang kecanduan rokok konvensional, yang mulai mengerti bahwa menggunakan e-cigarette (vaping) lebih aman dibandingkan dengan merokok konvensional. Terbukti di tahun 2015, Laporan Kesehatan Masyarakat Inggris menyatakan bahwa e-cigarette bisa jadi 95\% lebih tidak berbahaya daripada rokok konvensional. Menurut Departemen Kesehatan Indonesia, Electronic Nicotine Delivery Systems (ENDS) atau dengan nama lain rokok elektronik mengandung bahan-bahan berbahaya bagi kesehatan. Adapun 
macam-macam bahan berbahaya tersebut antara lain Nikotin, Propilen Glikol dan Gliserin, Flavoring (Perisa) yang terdapat dalam liquid rokok elektronik. Selain itu adapula zat karbonil seperti Formaldehid, Asetaldehid, Akrolein dan Logam (Timbal dan Kromium) yang merupakan komposisi toksik aerosol (Uap) pada rokok elektroni (BPOM, 2017). Apabila formaldehid terpapar di tubuh manusia dalam waktu 15 hari, dapat menyebabkan stres oksidatif juga kerusakan DNA pada sumsum tulang dimana keduanya akan mengganggu sistem respirasi dan sirkulasi, seperti Saturasi Oksigen dan Arus Puncak Ekspirasi. (Bhatnagar,A. Curr Cardiovasc Risk Rep, 2016).

Electronic cigarette (rokok elektronik) atau ecigarette merupakan salah satu NRT yang menggunakan listrik dari tenaga baterai untuk memberikan nikotin dalam bentuk uap dan oleh WHO disebut sebagai Electronic Nicotine Delivery System (ENDS). Electronic cigarette dirancang untuk memberikan nikotin tanpa pembakaran tembakau dengan tetap memberikan sensasi merokok pada penggunanya. Electronic cigarette diciptakan di Cina lalu dipatenkan tahun 2004 dan dengan cepat menyebar ke seluruh dunia dengan berbagai merek seperti NJOY, EPuffer, blu cigs, green smoke, smoking everywhere, dan lain-lain. Secara umum sebuah ecigarette terdiri dari 3 bagian yaitu: battery (bagian yang berisi baterai), atomizer (bagian yang akan memanaskan dan menguapkan larutan nikotin) dan catridge (berisi larutan nikotin).

Arus Puncak Ekspirasi (APE) adalah kecepatan maksimum aliran udara yang didapatkan saat melakukan ekspirasi paksa secara cepat dan kuat yang didahului dengan inspirasi secara maksimal. Jika APE tidak sesuai dengan nilai skala normal, berarti ada hambatan aliran udara pada saluran pernapasan yang mengakibatkan aliran udara yang keluar tidak maksimal (Alimatabrina, 2015). Arus puncak ekspirasi ini dapat diukur menggunakan Peak Flow Meter (Sherwood, 2011).

Ada beberapa faktor yang mempengaruhi hasil dari APE yaitu umur, jenis kelamin, ras, indeks masa tubuh (IMT), kebiasaan merokok, olah raga dan faktor lingkungan. Faktor lingkungan dapat mempengaruhi oleh beberap hal seperti polusi udara dan lingkungan kerja. Zat yang paling banyak pengaruhnya terhadap saluran pernapasan dan paru adalah sulfur dioksida (SO2). Nitrogendioksida (NO2) dan ozon yang tinggi pada udara dapat menginduksi reaksi inflamasi pada paru dan gangguan sistem imunitas pada tubuh (Novarin, 2014). Nilai arus puncak ekspirasi terdiri dari 3 jenis, yaitu (Lasmana, 2010) arus puncak ekspirasi (APE) sesaat, arus puncak ekspirasi (APE) tertinggi dan arus puncak ekspirasi (APE) harian. Penelitian Joko 2004 menyatakan rokok mempengaruhi fungsi dari faal paru yaitu menurunkan nilai APE, nilai aktual APE untuk perokok yaitu 496 L/min dengan nilai prediksinya $85,1 \%$ lebih rendah dari pada nilai aktual APE yang bukan perokok yaitu. 589,5 L/min dengan nilai prediksinya 108,9\% (Joko, 2004).

\section{METODE}

Desain penelitian ini adalah analitik kuantitatif, yaitu dengan pendekatan Cross Sectional, yaitu dengan cara pengumpulan data sekaligus pada suatu waktu (Notoatmodjo, 2012). 
Populasi pada penelitian ini peneliti mengambil sampel mahasiswa kedokteran Universitas Malahayati angkatan 2015, 2016 dan 2017, yang berjumlah 335 orang. Jumlah sampel yang digunakan pada penelitian ini sebanyak 66 orang yang sesuai dengan kriteria inklusi yaitu Mahasiswa Kedokteran angkatan 2015, 2016, dan 2017, merokok vape minimal 3 bulan, merokok konvensional minimal 3 bulan, bersedia menjadi responden penelitian dengan menandatangani informed consent dan kriteria ekslusinya yaitu menderita penyakit saluran pernafasan akut (Batuk, Flu, Demam), menderita penyakit saluran pernapasan kronis (Tuberkulosis, Asma, Rhinitis Alergi dan Keganasan) serta pemakaian dual user, sampel tersebut dihitung berdasarkan rumus Slovin (Notoatmodjo, 2010). Lokasi penelitian di lingkungan Universitas Malahayati Kota Bandar Lampung. Pelaksanaan penelitian pada bulan Januari 2019 yang dimulai dengan mengumpulan data. Alat pengumpulan data menggunakan informed consent. Alat ukur penelitian ini menggunakan peak flow meter. Cara penelitian dimulai dari responden dikumpulkan didalam ruangan, dijelaskan maksud tujuan penelitian, responden diminta mengisi lembar informed consent, dilakukan pengukuran arus puncak ekspirasi, dan pencatatan hasil pengukuran pada formulir lembar penelitian. Hasil data penelitian ini diolah dengan menggunakan uji mann whitney test pada program komputer IBM SPSS Statistics 23.

\section{HASIL}

Penelitian ini dilakukan di Kampus Universitas Malahayati Bandar Lampung pada bulan Januari 2018. Penelitian ini untuk mengetahui perbedaan nilai arus puncak ekspirasi (APE) perokok elektronik dan perokok konvensional pada mahasiswa Kedokteran Universitas Malahayati. Jumlah sampel yang diperoleh sebanyak 66 sampel yang terdiri dari 33 sampel perokok konvensional dan 33 sampel perokok elektronik yang memenuhi kriteria inklusi dan eksklusi. Pengambilan sampel dilakukan secara purposive sampling. Dari penelitian yang dilakukan dengan pengambilan data dan pengisian informed consent pada Mahasiswa Kedokteran Malahayati yang merupakan perokok elektronik dan perokok konvensional diperoleh hasil sebagai berikut:

Tabel 1. Distribusi karakteristik Sampel

\begin{tabular}{|c|c|c|c|}
\hline \multirow[t]{2}{*}{ Variabel } & \multicolumn{2}{|c|}{ Status penggunaan } & \multirow[t]{2}{*}{ Total } \\
\hline & Elektronik & Konvensional & \\
\hline \multicolumn{4}{|l|}{ Usia (tahun) } \\
\hline 19 tahun & 9 & 9 & 18 \\
\hline 20 tahun & 11 & 12 & 23 \\
\hline 21 tahun & 9 & 3 & 12 \\
\hline 22 tahun & 4 & 9 & 13 \\
\hline \multicolumn{4}{|c|}{ Lama Merokok (bulan) } \\
\hline 6 bulan & 3 & 1 & 4 \\
\hline 7 bulan & 2 & 1 & 3 \\
\hline 8 bulan & 8 & 3 & 11 \\
\hline 9 bulan & 1 & 3 & 4 \\
\hline 10 bulan & 2 & 8 & 10 \\
\hline 11 bulan & 1 & 5 & 6 \\
\hline
\end{tabular}




\begin{tabular}{lccc}
12 bulan & 16 & 12 & 28 \\
Nilai Pneumobile & 28 & 11 & 39 \\
$80 \%-100 \%$ & 5 & 22 & 27 \\
$50 \%-79 \%$ & 0 & 0 & 0 \\
$\leq 50 \%$ & & & \\
\hline
\end{tabular}

Dari tabel 1 dapat dilihat bahwa pada usia 19 tahun terdapat 9 perokok elektronik $(13,6 \%)$ dan 9 perokok konvensional $(13,6 \%)$, usia 20 tahun terdapat 11 perokok elektronik $(16,7 \%)$ dan 12 perokok konvensional $(18,2 \%)$, usia 21 tahun terdapat 9 perokok elektonik $(13,6 \%)$ dan 3 perokok konvensional $(4,5 \%)$ dan pada usia 22 tahun terdapat 4 perokok elektronik $(6,1 \%)$ dan 9 perokok konvensional $(13,6 \%)$. Dari total 66 mahasiswa dengan persentase $100 \%$ menunjukan riwayat lama merokok dengan rentang waktu 6-12 bulan terdapat paling banyak pada 12 bulan dengan jumlah sebanyak 16 perokok elektronik $(24.2 \%)$ dan 12 perokok konvesional $(18,1 \%)$. Pada tabel 1 dapat dilihat bahwa pada pada nilai APE $80 \%-100 \%$ terdapat 28 perokok elektronik $(42,4 \%)$ dan 11 perokok konvensional (16,7\%), kemudian nilai APE 50\%-79\% terdapat 5 perokok elektronik $(7,6 \%)$, dan 22 perokok konvensional (33,3\%), sedangkan tidak terdapat perokok elektronik ataupun perokok konvensional yang nilai APE nya kurang dari $50 \%$.

Tabel 2. Rata - rata Presentase APE Perokok Elektronik dan Perokok Konvensional

\begin{tabular}{cccc}
\hline \multirow{2}{*}{ Kelompok } & \multicolumn{3}{c}{ Nilai Arus Puncak Ekspirasi (\%) } \\
\cline { 2 - 4 } & Mean \pm SD & Median & Min - Max \\
\hline Perokok Elektronik & $89,39 \pm 8,120$ & 92 & $69-100$ \\
Perokok Konvensional & $77,36 \pm 8,336$ & 76 & $61-99$ \\
\hline
\end{tabular}

Tabel 3. Hasil uji statistik Mann-Whitney untuk membandingkan nilai APE Perokok Elektronik dan Perokok Konvensional

\begin{tabular}{cccc}
\hline \multirow{2}{*}{ Kelompok } & \multicolumn{3}{c}{ Nilai Arus Puncak Ekspirasi (\%) } \\
\cline { 2 - 4 } & Mean \pm SD & Mean Different & P \\
\hline Perokok Elektronik & $89,39 \pm 8,120$ & \multirow{2}{*}{12,03} & 0,000 \\
Perokok Konvensional & $77,36 \pm 8,336$ & & \\
\hline
\end{tabular}

Dari tabel 4 dapat dilihat bahwa ratarata nilai APE subjek penelitian pada kelompok perokok elektronik adalah sebesar $89,39 \%$ dengan median atau nilai tengah sebesar $76 \%$ dan nilai minimal APE subjek sebesar 69\% serta nilai maksimalnya sebesar $100 \%$ dengan standar deviasi sebesar 8,120. Sedangkan rata-rata nilai APE subjek penelitian pada kelompok perokok konvensional adalah sebesar 77,36\% dengan nilai tengah sebesar $96 \%$ dan nilai minimal APE subjek sebesar $61 \%$ serta nilai maksimalnya sebesar $100 \%$ dengan standar deviasi sebesar 8,336.

Berdasarkan tabel 5 hasil analisis uji Mann-Withney dengan tingkat kesalahan 10\% menggunakan SPSS 23 antara kelompok perokok konvensional dan kelompok perokok elektronik didapatkan nilai probabilitas atau nila $p$ - value sebesar 0,000. Oleh karena nilai $p<0,1$ maka hipotesis Ho ditolak dan nilai Ha diterima yang berarti bahwa terdapat perbedaan yang bermakna antara APE pada Mahasiswa Kedokteran dengan status perokok elektronik dan perokok konvensional di Universitas Malahayati Tahun 2019. Kemudian untuk rata-rata APE pada mahasiswa perokok elektronik sebesar 89,39\% dan rata-rata APE pada mahasiswa perokok konvensional sebesar 77,36\%, sehingga dapat disimpulkan bahwa nilai rata-rata APE pada mahasiswa perokok elektronik lebih besar dari nilai rata-rata APE pada mahasiswa perokok konvensional dengan selisih data sebesar 12,03\%.

\section{PEMBAHASAN}


Berdasarkan hasil penelitian dapat diketahui bahwa karakteristik subjek penelitian baik itu perokok elektronik dan perokok konvensional berdasarkan usia, dari total mahasiswa yang merokok paling banyak pada rentang usia remaja akhir (Depkes RI, 2009) yaitu 19-21 tahun dengan jumlah total pada penelitian ini sebanyak 66 mahasiswa. Hal ini sesuai dengan hasil penelitian Global Youth Tobacco Survey, Indonesia Report (2014) yang menyatakan bahwa proporsi perokok di Indonesia berdasarkan usia adalah perokok usia 5-9 tahun sebesar 0,7 \%, usia 10-14 tahun sebesar 9,5\%, usia 15-20 tahun sebesar 50,3\%, usia 20-24 tahun sebesar 26,7 \%, usia 25-29 tahun sebesar $7,6 \%$ dan usia 30 tahun sebesar 5,2 \%. Data tersebut menunjukan bahwa memang usia perokok paling banyak pada usia 1520 tahun (Kemenkes, 2013).

Hal tersebut berbeda dengan penelitian Rizaldy (2016) dikarenakan subjek penelitiannya adalah siswa SMK, Hal tersebut juga berbeda dari penelitian Ardha (2018) dan Noortiningsih (2017) dimana subjek penelitiannya adalah siswa SMP, serta penelitian Erawati (2014) dimana subjek penelitian terbanyak pada usia 45-54 tahun dan penelitian Januaristi (2018) dengan rentang usia terbanyak pada usia 25-34 tahun. Rentang usia pada penelitian ini sama dengan dalam Fadli (2017) dikarenakan penelitian dilakukan pada mahasiswa. Banyaknya mahasiswa yang merokok pada rentang usia 19-25 tahun tidak lepas dari adanya hubungan tuntutan akademik yang dapat membuat mahasiswa sangat rentan mengalami stres (Gaol, 2016). Menurut Kurt Lewin pada remaja, faktor dari dalam diri terkait dengan adanya krisis psikososial yang dialami pada masa perkembangannya yaitu masa dimana mereka mencari jati diri. Remaja menjadi seorang perokok karena berusaha untuk mencari kompensasi atau usaha kompensatoris dalam upaya pencarian jati diri (Tristanti I, 2016). Berdasarkan hasil penelitian dapat diketahui bahwa karakteristik subjek penelitian baik itu perokok elektronik dan perokok konvensional berdasarkan riwayat lama merokok menurut status penggunaan pada penelitian ini, dalam rentang waktu 6-12 bulan, untuk perokok konvensional menunjukkan paling banyak sudah menggunakan rokok selama 12 bulan. Sementara untuk perokok elektronik juga menunjukkan bahwa responden terbanyak telah menggunakan rokok elektronik selama 12 bulan. Hal ini tidak serupa dengan penelitian yang dilakukan oleh Rizaldy (2016) dimana lama merokok subjek penelitiannya paling banyak dalam tingkatan 3-5 tahun. Hal ini juga tidak serupa dengan penelitian Kosmider (2017) dimana subjek penelitian untuk penggunaan rokok elektronik paling banyak pada tingkatan 3-6 Bulan dan penelitian Polosa (2017) dimana subjek terbanyak pada tingkatan penggunaan selama 3,5 tahun.

Untuk terjadinya obstruksi (hambatan) pada jalan nafas yang disebabkan oleh asap rokok terdapat beberapa faktor seperti lama merokok, jumlah batang rokok yang dikonsumsi perhari, dan olahraga (life style) (Patrianto dan Yunus, 2005). Berdasarkan tabel 3 maka diketahui persentase nilai APE perokok elektronik dan perokok konvensional pada Mahasiswa Kedokteran Universitas Malahayati. Jumlah mahasiswa yang merokok dengan kategori persentase nilai APE $50-79 \%$ sebanyak 27 mahasiswa dengan persentase 40,9\%, dan kategori APE 80-100\% berjumlah 39 
mahasiswa dengan persentase $59,1 \%$. Pada penelitian ini nilai arus puncak ekspirasi mahasiswa yang merokok masih banyak yang dalam batas normal, akan tetapi ada mahasiswa yang arus puncak ekspirasinya kurang normal yaitu sebesar 40,9\%.

Hal tersebut sesuai dengan penelitian yang menjelaskan bahwa kandungan dari rokok elektronik dapat memberikan dampak bagi sistem kardiorespirasi dengan cara mengiritasi saluran napas atas maupun bawah, memiliki efek bronkokontriksi, dan merusak struktur parenkim paru. (Reinikovaite, 2018). Hal tersebut juga membuktikan bahwa efek dari penggunaan rokok elektronik ternyata tidak seperti yang diklaim selama ini (bahwa rokok elektronik tidak memiliki efek sedikitpun). Hasil ini didukung oleh penelitian Antoniewicz (2016) dimana diketahui bahwa penggunaan rokok elektronik meningkatkan kadar sel progenitor dalam pembuluh darah dan pada penelitian Rohmani (2018) dimana didapatkan kerusakan sedang pada gambaran histologis paru pada tikus Rattus novergicus akibat adanya paparan asap rokok elektronik. Penelitian Glynos (2017) juga mengungkapkan bahwa kandungan dalam rokok elektronik dapat memicu inflamasi paru dan dapat menyebabkan perubahan mekanisme pernapasan. Hasil ini sesuai dengan Penelitian The Global Initiative for Chronic Obstructive Lung Disease (GOLD) menunjukkan hasil adanya hubungan antara kebiasaan merokok dengan penurunan fungsi paru VEP1/KVP dan FEF 25-75\%

Untuk terjadinya obstruksi (hambatan) pada jalan nafas yang disebabkan oleh asap rokok terdapat beberapa faktor seperti lama merokok, jumlah batang rokok yang dikonsumsi perhari, dan olahraga (life style) (Patrianto dan Yunus, 2005). Penelitian yang dilakukan oleh tarigan 2008 menyebutkan bahwa ada pengaruh latihan otot pernapasan untuk meningkatkan volume ekspirasi paksa detik pertama pada kelompok intervensi. Asap rokok yang mengandung campuran kompleks antar 4700 bahan kimia, termasuk radikal bebas dan oksidan dalam konsentrasi tinggi. Beban oksidan bertambah dalam paru akibat pelepasan Reactive Oxygen Species dari makrofag dan neutrofil. Asap rokok tersebut mengurangi kapasitas antioksidan diplasma berkaitan dengan penurunan protein sulfhydryl di plasma atau glutathione. Penurunan ini menyebabkan peningkatan lipid peroksidase dan transkripsi sitoin yang berperan pada obstruksi paru (Deveruex, 2006). Dan ini menyebabkan menurunnya nilai arus puncak ekspirasi pada perokok. Polusi udara juga dapat menurunkan arus puncak ekspirasi yang mengandung gas $\mathrm{SO} 2, \mathrm{NO} 2$, dan debu diketahui dapat mempengaruhi nilai FVC dan FEV1. Konsentrasi gas SO2 dan NO2 yang kecil sekalipun namun apabila terinhalasi setiap hari dapat menimbulkan gangguan fungsi paru (Sandra C, 2013)

Analisis Perbandingan Nilai APE Status Perokok

Berdasarkan uji normalitas Kolmogorov Smirnov bahwa data tidak terdistribusi normal, dimana hasil olah data didapatkan nilai $p=$ 0,032 , yang berarti $p<0,05$ bahwa data tidak terditribusi normal. Sehingga tidak dapat dilakukan uji TTest Independent. Kemudian berdasarkan hasil uji homogenitas Levene's Test didapatkan $p=0,066$, yang berarti $p>0,05$ dan disimpulkan bahwa data yang diambil homogen. Dikarenakan data 
tidak terdistribusi normal tetapi data homogen, maka dilakukan uji MannWhitney Test. Hasil analisis uji Mann-Withney dengan tingkat kesalahan $10 \%$ menggunakan SPSS 23 antara kelompok perokok konvensional dan kelompok perokok elektronik didapatkan nilai probabilitas atau nila $p$ - value sebesar 0,000 . Oleh karena nilai $p<$ 0,1 maka hipotesis Ho ditolak dan nilai Ha diterima yang berarti bahwa terdapat perbedaan yang bermakna antara APE pada Mahasiswa Kedokteran dengan status perokok elektronik dan perokok konvensional di Universitas Malahayati Tahun 2019. Kemudian untuk rata-rata APE pada mahasiswa perokok elektronik sebesar 89,39\% dan rata-rata APE pada mahasiswa perokok konvensional sebesar 77,36\%, sehingga dapat disimpulkan bahwa nilai rata-rata APE pada mahasiswa perokok konvensional lebih kecil dari nilai rata-rata APE pada mahasiswa perokok elektronik dengan selisih data sebesar $12,03 \%$.

Hal ini sesuai dengan teori yang menyatakan untuk terjadinya obstruksi (hambatan) pada jalan nafas yang disebabkan oleh asap rokok terdapat beberapa faktor seperti lama merokok, jumlah batang rokok yang dikonsumsi perhari, dan olahraga (life style) (Patrianto dan Yunus, 2005). Penelitian yang dilakukan oleh tarigan 2008 menyebutkan bahwa ada pengaruh latihan otot pernapasan untuk meningkatkan volume ekspirasi paksa detik pertama pada kelompok intervensi. Rokok elektrik memiliki tiga zat utama, yaitu Nikotin, Propylene Gylcol, dan Glycerine. Kandungan nikotin dalam rokok elektrik jauh lebih sedikit dibandingkan dengan yang ada pada rokok konvensional. Sementara untuk propylene glycol dan gliserin merupakan bahan yang dinyatakan aman oleh Food and Drugs Association (FDA). Rokok elektrik sendiri mengandung tembakau dan tidak mengalami proses 'pembakaran' sehingga tidak menghasilkan CO, dimana pada rokok konvensional, CO merupakan faktor utama yang menyebabkan pasukan oksigen ke jaringan menurun. Terbukti di tahun 2015, Laporan Kesehatan Masyarakat Inggris menyatakan bahwa ecigarette bisa jadi 95\% lebih tidak berbahaya daripada rokok konvensional. Namun hal tersebut bukan berarti rokok elektrik tidak memiliki efek terhadap sistem kardiorespirasi karena hasil penelitian The Global Initiative for Chronic Obstructive Lung Disease (GOLD) menunjukkan hasil adanya hubungan antara kebiasaan merokok dengan penurunan fungsi paru VEP1/KVP dan FEF 25-75\%. Menurut banyak penelitian, diantaranya yang dilakukan oleh Qasim (2016), Glynos (2017), Reinikovaite (2018), Antoniewicz (2018), Rohmani (2018) dan Larcombe (2017), membuktikan bahwa rokok elektrik memiliki efek terhadap penurunan fungsi parenkim paru pada kapasitas residual fungsional dan mengakibatkan tekanan trans-respiratori yang tinggi. Selain itu juga dapat mengakibatkan perubahan pada struktur parenkim paru, perubahan dinding pembuluh darah, gangguan kontraktilitas otot jantung dan masih banyak lagi.

Hal ini berbeda dengan penelitian yang menyatakan penurunan fungsi paru akan mulai terlihat pada lama pernapasan yang terjadi pada 2 tahun dan seterusnya akibat debu dan kebiasaan merokok" (Herminto, 1998 dalam Basuki SW 2013). Rokok bertanggung jawab untuk lebih dari $90 \%$ dari penyakit saluran pernapasan obstruktif kronis dalam satu sampai dua tahun dari Merokok 
secara teratur (Abdulrahman WF, 2011). Akan tetapi pada penelitian ini riwayat lama merokok pada mahasiswa paling banyak yaitu kurang dari dua tahun karena jangka waktu yang diambil dalam penelitian ini hanya $6-12$ bulan. Pembagian kelompok umur sesuai dengan pembagian kelompok umur pada penelitian pneumobile. Kelompok umur 19-21 tahun memiliki interval lebih pendek daripada kelompok lain karena secara biologis faal paru mencapai puncaknya pada umur tersebut kemudian menurun. Penelitian yang dilakukan oleh Medabala (2013), pada masyarakat di Andhra Pradesh (India) dengan usia 20-40 tahun, bahwa "penurunan PEFR yang lebih besar seiring dengan bertambahnya usia dan jumlah penggunaan rokok". Sedangkan pada penelitian ini usia seluruh sampel yang berumur 19-21 tahun. Maka dari itu menyebabkan nilai arus puncak ekspirasinya menurun tidak terlalu rendah karena belum terjadi penurunan fungsi paru yang berat pada responden penelitian atau bahkan baru dimulai terjadi penyempitan disaluran pernapasan tetapi belum parah, yang dapat menyebabkan perubahan pada fungsi paru yang membuat penurunan yang signifikan pada nilai APE.

Kemudian hasil penelitian ini sesuai dengan teori yang mengatakan bahwa secara luas telah diketahui bahwa menggunakan rokok konvensional dapat mengurangi "napas". Hal ini benar dengan berbagai alasan. Pertama, salah satu efek nikotin adalah konstriksi bronkiolus terminal paru, yang meningkatkan tahanan aliran udara ke dalam dan ke luar paru. Kedua, efek iritasi asap rokok itu sendiri menyebabkan peningkatan sekresi cairan ke dalam cabang-cabang bronkus, juga pembengkakan lapisan epitel. Ketiga, nikotin melumpuhkan silia pada permukaan sel epitel pernapasan yang normalnya terus bergerak untuk memindahkan kelebihan cairan dan partikel asing dari saluran pernapasan. Akibatnya, lebih banyak debris terakumulasi di jalan napas dan menambah kesulitan bernapas.

Gas SO2, NO2, dan debu diketahui dapat mempengaruhi nilai FVC dan FEV1. Konsentrasi gas SO2 dan $\mathrm{NO} 2$ yang kecil sekalipun namun apabila terinhalasi setiap hari dapat menimbulkan gangguan fungsi paru. Polutan udara yang dapat mengakibatkan gangguan pada saluran pernafasan adalah gas NO2, SO2, formaldehid, ozon, dan partikel debu. Polutan tersebut bersifat mengiritasi saluran pernafasan yang dapat mengakibatkan gangguan fungsi paru. Gas SO2 dapat menimbulkan efek iritasi pada saluran pernafasan bagian atas karena mudah larut dalam air yang mengakibatkan produksi lendir meningkat sehingga terjadi penyempitan pada saluran pernafasan. Nitrogen dioksida bersifat iritan dan radikal. Gas (Sandra C, 2013). Merokok kronis terlebih lagi dapat menyebabkan penyakit yang lebih berat lagi. Beberapa diantaranya adalah penyakit emfisema, dimana pada penyakit tersebut, terdapat beberapa kondisi seperti: bronchitis kronis, destruksi sebagian dindin alveolus serta terjadinya obstruksi pada bronkioli. Kondisi-kondisi tersebut tentunya akan menyebabkan pasien tidak dapat melakukan kegiatan kegiatan sederhana tanpa adanya kelelahan (Hall, 2014). Maka berdasarkan hasil penelitian secara keseluruhan dan berdasarkan sumber dari peneliti sebelumnya, peneliti menyetujui bahwa terdapat perbedaan yang bermakna antara nilai APE pada perokok elektronik 
dan perokok konvensional yang mana nilai APE pada akan berpengaruh terhadap fungsi paru dan juga bisa sebagai bahan acuan adanya sumbatan atau obstruksi pada saluran pernapasan.

\section{KESIMPULAN}

Terbukti terdapat perbandingan bermakna nilai arus puncak ekspirasi $(p<0,001) \quad$ perokok elektronik $(89,39 \pm 8,120)$ dan perokok konvensional $(77,36 \pm 8,336)$ pada mahasiswa kedokteran Universitas Malahayati di Kota Bandar Lampung tahun 2019. Dimana APE perokok konvensional lebih rendah karena rokok konvensional lebih cepat menimbulkan obstruksi saluran pernafasan dibandingkan dengan rokok elektrik.

\section{SARAN}

Bagi mahasiswa diharapkan untuk mulai mengurangi kecanduan merokok konvensional dengan beralih menggunakan rokok elektronik (vape) meskipun harganya cenderung lebih mahal, tetapi pada hasil penelitian ini memperlihatkan bahwa efek rokok elektronik lebih aman dibandingkan rokok konvensional dalam segi pengaruhnya terhadap APE dan fungsi paru. Bagi Universitas diharapkan dengan adanya penelitian ini dapat menjadi acuan untuk menyelenggarakan program penanggulangan perilaku merokok pada mahasiswa Kedokteran di Universitas Malahayati.

\section{DAFTAR PUSTAKA}

Alsagaff, $H .$, \& Mangunegoro, $H$. (1987). Nilai Normal Faal Paru Orang Indonesia pada Usia Sekolah dan Pekerja Dewasa Berdasarkan Rekomendasi American Thoracic Society.
Brown, J., Beard, E., Kotz, D., Michie, S., \& West, R. (2014). Real-world effectiveness of ecigarettes when used to aid smoking cessation: a crosssectional population study. Addiction, 109(9), 1531-1540.

Choi, K., \& Forster, J. (2013). Characteristics associated with awareness, perceptions, and use of electronic nicotine delivery systems among young US Midwestern adults. American journal of public health, 103(3), 556-561.

Dawkins, L., Turner, J., Roberts, A., \& Soar, K. (2013). 'Vaping'profiles and preferences: an online survey of electronic cigarette users. Addiction, 108(6), 1115-1125.

Dastyawan, B. (2000). Pengaruh Asap Rokok Terhadap Saluran Pernapasan.

East, K., Hitchman, S. C., Bakolis, I., Williams, S., Cheeseman, H., Arnott, D., \& McNeill, A. (2018). The association between smoking and electronic cigarette use in a cohort of young people. Journal of Adolescent Health, 62(5), 539547.

Guyton, A. C., \& Hall, J. E. (2007). Buku ajar fisiologi kedokteran edisi 11. Jakarta: EGC, 81-85.

Istiqomah, D. R., Cahyo, K., \& Indraswari, R. (2016). Gaya Hidup Komunitas Rokok Elektrik Semarang Vaper Corner. Jurnal Kesehatan Masyarakat (eJournal), 4(2), 203-212.

Moore, D., Aveyard, P., Connock, M., Wang, D., Fry-Smith, A., \& Barton, P. (2009). Effectiveness and safety of nicotine replacement therapy assisted reduction to stop smoking: systematic review and metaanalysis. Bmj, 338, b1024. 
Mishra, S. (2017). Are e-cigarettes beneficial for public health: Hume's guillotine-The debate continues?.

Notoatmodjo, S. (2010). Metodologi penelitian kesehatan.

Pearson, J. L., Richardson, A., Niaura, R. S., Vallone, D. M., \& Abrams, D. B. (2012). eCigarette awareness, use, and harm perceptions in US adults. American journal of public health, 102(9), 1758-1766.

Prabandari, Y. S. (2009). Kawasan tanpa rokok sebagai alternatif pengendalian tembakau studi efektivitas penerapan kebijakan kampus bebas rokok terhadap perilaku dan status merokok mahasiswa di fakultas kedokteran UGM, Yogyakarta. Jurnal Manajemen Pelayanan Kesehatan, 12(04).

Price Sylvia, A., \& Wilson Lorraine, M. (1995). Patofisiologi Konsep Klinis Proses-Proses Penyakit. Jakarta: Penerbit Buku Kedokteran EGC, 1.

Rahmadi, A., Lestari, Y., \& Yenita, Y. (2013). Hubungan pengetahuan dan sikap terhadap rokok dengan kebiasaan merokok siswa smp di kota padang. Jurnal kesehatan andalas, 2(1), 25-28.

Hukum, K. (2012). Peraturan Pemerintah Republik Indonesia Nomor 109 Tahun 2012 tentang pengamanan bahan yang mengandung zat adiktif berupa produk tembakau bagi kesehatan.

Riskesdas. 2013. Perilaku Merokok Masyarakat Indonesia. Infodatin Pusat Data dan Informasi Kementrian Kesehatan RI. Jakarta.

London, R. C. P. (2016). Nicotine without smoke: Tobacco harm reduction. RCP Lond, 908.
Wang, X., Zhang, X., Xu, X., \& Gao, Y. (2018). Electronic cigarette use and smoking cessation behavior among adolescents in China. Addictive behaviors, 82,

World Health Organization. (2015). Advisory note: global nicotine reduction strategy: WHO Study Group on Tobacco Product Regulation.

World Health Organization. (2012). Global adult tobacco survey: Indonesia report 2011. 